\title{
A new and old pandemic - the burnout syndrome
}

\begin{abstract}
The Burnout Syndrome (SB) is known worldwide, but scientific studies only started from the researches made by the American psychologist Freudenberger. Its concept encompasses three dimensions: emotional exhaustion, depersonalization and low professional achievement. It is currently a student in various fields of human knowledge, from Anthropology to Psychology. The area of Psychology that most researchers BS is the Psychodynamics of Work in which they call it "Malaise". However, researchers involving BS under the perspective of Behavior Analysis is scarce in Brazil and in the world. This study aims to analyze BS in several countries, from developed to poor countries, and in this sense supports the thesis that it is a pandemic. It is a study of a theoretical nature, of qualitative, descriptive and bibliographic nature and has as theoretical basis Skinner's Radical Behaviorism.
\end{abstract}

Keywords: burnout syndrome, behavior analysis, pandemic, coping
Volume 6 Issue I - 202 I

\author{
José Francisco de Sousa \\ Departmnet of sychology Pos-Graduate Programa, Catholic \\ Universif of Brasilia, Brazil
}

\begin{abstract}
Correspondence: José Francisco de Sousa, Departmnet of sychology Pos-Graduate Programa, Catholic Universif of Brasilia,
\end{abstract} Brazil,Tel 5561999715145, Emal francisco1965@gmail.com

Received: January 18, 2021 | Published: February 03, 2021

\section{Introduction}

The whole world pays attention to a pandemic that has killed millions of people worldwide, caused by the COVID-19 virus. However, historically humanity has gone through several turbulent periods with various epidemics, such as the bubonic plague, in the 14th century that killed about of a third of the European population . The epidemic that wiped out millions of indigenous people in America caused by a virus brought by the Europeans, and more recently, the Spanish flu, not to mention smallpox, a disease that perpetuated for more than three thousand years and the cholera in the early 19th century. All of these diseases had in common a pathological agent :a bacteriam or a virus.

But, there are other diseases that are invisible because they are psychological or psychiatric, such as depression. This in turn, according to data from the World Health Organization, affects more than 300 million people worldwide and is considered one of the main causes of absence from work together with anxiety. Data from the Brazilian government estimated between 2012 and 2018, acording to the National Institute of Social Security (INSS) spent more than R\$ 85 millions to hold sickness support it self. These same data pointed to the year 2016 that 78 thousand people were removed from work, while the following year the number increased to 178 thousand of employees.

Due to this invisibility, the mentals illnesses / mentals disorders in historical terms have always existed, being understood in different ways by different cultures (eg in ancient times, among the Greeks, madness had a mix of myth that mixed with the normality; in the Middle Ages, under the strong influence of the Catholic Church, was attributed to Satan, the enemy of God. Only in the Modern Age, with the Renaissance and the Illumination, the madness leaves the world of natural or divine forces and becomes the opposite of the loss of reason , and than, the first studies on the subject begin) but its treatment is recent, as well as the appearance and understanding of new mentals illnesses / disorders, as in the Burnout Syndrome.

This essay aims to discuss the Burnout Syndrome (SB) understand as a silent pandemic that has affected thousands of workers worldwide and with that, productivity, and in the future, even the productive systems, because the workers due to intense exploitation of working the and new global settings.
The main characteristic of BS is physical and mental exhaustion, when the individual feels that he no longer has the energy to make small achievements, because the work activities does not allow to, and are emotionally overloaded. There are also two other important characteristics of SB, such as depersonalization and lack of interest in the work actives, which we will discuss in the topics below. A clearer definition of BS is based on the sociopsychological perspective, which considers BS as a chronic response to interpersonal stressors arising from the work situation, since the work environment and its organization may be responsible for the suffering and wear and tear that affects workers. ${ }^{1-3}$ For Behavior Analysis, environmental factors are important sources of illness among workers, as well as the lack of a capable behavioral repertoire. to face the contingencies arising from the environment itself, in addition, the lack of reinforcers and stimuli at work, affect workers, making them sick.

\section{Contextualizing}

This essay aims to discuss the burnout syndrome, understanding that it is a silent pandemic that affectes thousands of workers from all over the world, thereby affecting productivity, and in the future, even the productive systems because workers due intense labor exploitation and the technological emprovement.

Since the advent of the Industrial Revolution in the 17th century and especially in the late 19th century with the advent of new inventions that replaced human's manual labor, several workers-related physiccal and psychogical diseases. At the beginning of the 18th century, the Italian physician Bernardino Ramazzini published his first work on occupational diseases - De Morbis Artificum Diatriba. ${ }^{4}$

Over the years, several hygienic physicians began to worry about the relationship between work and illness and made several importants discoveries that benefited workers (eg Patissier who somehow helped French goldsmiths by recommending that they raise their heads to avoid . visual fadigue, as pointed out by Silva \& Paschoarelli. ${ }^{5}$ another example is the French physician Luis René Villemé, who associated excessive working hours, housing conditions, low wages, poor food versus the workers illness). Villemé had also found that half of the employer's children reached the age of 21 , while the worker's children would have 2 years less, as also related by Engels ${ }^{6}$ latedly (2007) founding the same results in England. 
However not only the Works relationships due social economics systems are the cause of Bunornout Syndrome been necessery avalueted such factores like individual and behavior, most envolvimental that may interfere directely or indirectely on prevalency of Burnout Syndrome. So, seans plausible that the afected individuals would be less propense to lide situation or multiplex stressors according environment, your resources and capacities.

Due conditions above, individual which weak behavior repertoire, would be more prone to the illness. Statiscally the reaserch all over the world, even Brazil has showed that the Burnout Syndrome is not a isolated phenomenon and not even a small relevance, by the way largest empical and theorical studies in grow has been shown to be an old disease but now growing Thousands workers. Some hypotheses has been elaborated: (1) the grown level of workers with Burnout Syndrome all around the world has increase in association wtih envolviromenal factores and mostly due global transformation and the labors lows. (2) the burnout syndrome has afected the productive and in consequence na inernational crises. (3) The Workd Health Organization (WHO) with its powers has important situation to delivery norms against the disease.

\section{The origin of burnout syndrome}

Years later, in the richest nation in the world, during the 1970s, Freudenberger $^{7}$ watching his fellow psychologists and himself, discovered that intense work was causing some symptoms in what he called Burnout Syndrome by identifying some physical signs (eg. exhaustion and fatigue, headaches, insomnia, gastrointestinal disorders, shortness of breath, etc.) and behavioral illness (irritation, anger, frustration, lack of control of feelings and emotions, frequent crying, fried and screaming, some paranoias, and sometimes, for relief the starts using drugs like tranquilizers and barbiturates).

At first, it was believed that the disease affected only a few workers, especially those who worked as caregivers of people, such as teachers, psysician, nurses, psychologists, but today, studies show that it affects any category, whether a worker or not. A survey by Martínez $\&$ Pinto $^{8}$ with university students in Spain and Portugal found high rates of burnout in these individuals. Waterway workers who are not caregivers of people are also affected by the Burnout Syndrome, as the research conducted by Silva, Souza, Soares, Teixeira et al 2018) ${ }^{9}$ with 430 employees of a waterway transportation company in the State of Rio de Janeiro. All of these studies and others point out that the environment, especially the behavioral one, is decisive in triggering the Burnout Syndrome. Most studies, both national and international, point to the influence of the environment as a source of the disease, which supports hypothesis 1 .

The World Health Organization (WHO) itself included it in the current World Classification of Diseases (ICD 11), thus admitting its incidence. According to ICD 11, Burnout Syndrome is understood to be the result of chronic stress in the workplace that has not been successfully managed. It is characterized by three dimensions: feelings of exhaustion or depletion of energy; increased mental distance from the work itself, or feelings of negativism or cynicism related to the work itself; reduced professional effectiveness. However, for WHO, the Syndrome is an exclusively occupational disease and should not be applied to other areas of life, returning to the initial concept and against scientific research. (PAHO / BRAZIL, 2020). This international organization plays an important role in guiding and disseminating scientific research, such as what is happening today with COVID and in the past with HIV. Thus, hypothesis 3 is also confirmed.

\section{Burnout's syndrome as a pandemic - all continents have the disease}

The burnout syndrome affects all social classes, all workers and is present on all continents. In the United States, Bakker \& Schaufeli ${ }^{10}$ showed the influence of organizational behavior for triggering the Burnout Syndrome. Another North American study by Fried \& Tiegs (1993) analyzed the effect of the engagement of workers in the automotive industry. North American scientific production with regard to the incidence of burnout syndrome grows every year, expanding to several professional categories, most showing that workers and companies are decreasing their productivity, and with this, products and services have become more expensive, according to hypothesis $2 .^{11,12}$ Canadian studies by Lee \& Ashforth ${ }^{13}$ associate models management with the incidence of burnout. The study was carried out with 148 supervisors who are managers of the human resources area and found that job and life satisfaction, as well as time spent with clients and subordinates, caused emotional exhaustion, and depersonalization.

Even North America, but now in an undeveloped country, Mexico, we found a lot of research on the incidence of burnout syndrome, especially in teachers ${ }^{14,15}$ and nurses.

While studies in North America are abundant, in Central America they are scarce. In Cosa Rica, for example, it is estimated that SB reaches 20 to $70 \%$ of workers, according to Sabório Morales \& Hidalgo Murillo ${ }^{16}$ who conducted a study involving a population of physician. But there are reports in this country of the incidence of SB in nurses, according to Bianchini Matamoros. ${ }^{17}$ Also in Costa Rica, Diaz Araya, ${ }^{18}$ in a cross-sectional study with 45 physicians, found that $20 \%$ of these professionals had BS and emotional exhaustion was the most affected dimension. Mackzie et al. ${ }^{19}$ in a survey of physicians in the Bahamas, residents, staffs and medical students had reported burnout symptoms in the category also significant emotional exhaustion, otherwise, doctors on field did not show any of the three dimensions. In El Salvador the prevalence of Burnout are between to $2.5 \%$ and $5.9 \%$ among professionals, ${ }^{20}$ in this country, there is a special highlight for social workers. ${ }^{21}$ We did not find researchs in Cuba, Barbados, Belize, Dominican Republic and other small countries. It is needed to emphasize the study made by Grau et al. ${ }^{20}$ regarding SB with a sample of 11,530 health professionals in Spanish spoken countries, one of the most complete written date recentely.

Somehow, researches on Burnout Syndrome in South American finds a fertile field and others various areas of knowledge and various professions (teachers of all levels, doctors from various areas). In Argentina, physicians are the hardest hit ${ }^{21}$ together with nurses ${ }^{22}$ and teachers. ${ }^{23}$ A survey by Jiménez, Figueroa et al. ${ }^{24}$ with a sample of 89 Chilean teachers who worked in municipal establishments showed considerable symptoms of Burnout, however, unlike other countries, Chilean teachers showed low levels of job satisfaction. Chilean studies pointed to a high level of burnout in service providers. Faúndez \& GilMonte ${ }^{25}$ with a sample of 393 workers from the Province of Valparaiso showed a high percentage of psychological distress (39.19\%) but in the same way as the teachers, they showed high personal achievement. In another survey, with a sample of 277 professional care for people with physical disabilities, the same researchers found out the same results. ${ }^{26}$ In addition to research with teachers, service providers and people caregivers, Chilean police officers (carabineiros) are also affected by the burnout syndrome. The explanations are due to the fact that these professionals deal with human problems of high complexity and impact, such as deaths from accidents, serious crimes, mistreatment, etc. ${ }^{27}$ 
The phenomenon of SB is universal and affects thousands of professionals from all continents and from all categories. Some researchers point out to one of the causes of BS the intense exploration of the work or the intense involvement with the work. At this point in our analysis we will first discuss the situation of African workers and then European workers, with an emphasis on the OECD countries (organization for Economic Cooperation and Development) which are the most developed countries in the world, while most African countries they are considered the poorest, contextualizing to better understand the situation.

Africa as well as any continent has very heterogeneous characteristics, both in social, political and economic aspects. Most countries are Arabic-speaking and the Muslim religion prevails. The climate is also very varied and even more varied are the societies that make up this great continent. In terms of research on BS in that continent, they are still incipient and only a few countries whose characteristic is democratic openness disseminate research on the situation of workers, but what is disclosed, mainly by the international press, is that conflicts, civil wars, hunger and physical illness is very common in Africa. A serious aspect in the African continent, according to data from the World Health Organization ${ }^{28}$ is the intense migratory flow that causes displacement or even "a substantial number of health workers leave the health workforce, either temporarily or permanently. ${ }^{28}$

In South Africa, a negative legacy after the apartheid system was the maintenance of low wages and often forced recruitment, ${ }^{29}$ and strict legislation, responsible for a high level of informality and subcontracting. ${ }^{30}$ Studies carried out in Nigeria among health professionals $^{31}$ who works in hospitals in Ghana (Fiadzo et al. ${ }^{32}$ psychiatric hospitals in Kenya (Ndetei et al. ${ }^{33}$ ) described similar findings. from the Kenyan country, high levels of depersonalization were observed in $47.8 \%$ of the psychiatric team, and high levels of emotional exhaustion and personal fulfillment around $38 \%$ and $37.3 \%$ respectively. ${ }^{33}$

In African countries, studies on burnout are scarce and most were only developed in the last decade of the 21 st century, as stated by Artal et al. ${ }^{11}$ who still adding the weakeness of health systems due to human resources, causing a crisis with the increasement of workload in care and teachers. In addition, we can also mention the lack of material resources, of the control over the work itself, inadequate and irregular working hours, , low wages and low career progression, and of course, in the case of psysicians, low job satisfaction. ${ }^{34}$

Following the United States and the countries of South America, studies on Burnout Syndrome in European countries are significantly in terms of amplitude and numerics. In foreign and national databases with descriptors using the words "Burnout Syndrome" followed by the name of the respectives countries, we found out incidences of BS, with the exception of the Vatican, San Marino, Malta, Monaco, Moldova, Armenia, Cyprus, Azerbaijan and Kazakhstan. One possible hypothesis is that these countries, besides being small, some live under authoritarian governments. However, researches and informations are lacking, but they do not imply the absence of suffering from workers with burnout symptoms. Our thesis intensifies the claim that it is a worldwide phenomenon caused by environmental changes at work, by intense exploration, pressures for productivity, etc.

Studies show that even Europeans countries part of the OECD have a high incidence of BS. A study with Austrian anesthesiologists conducted by Lederer, Kinzl, Trefalt „, Traweger \& Benzer (2005), pointing out the complexity of the work, the individual lack of time control (Austrian surgeons work less than anesthesiologists), the lack of participation in the work management and in the organization in which their works. On the physicians studied $(\mathrm{N}=26)$ presented physical complaints and dissatisfaction with their work. The authors concluded that working conditions that offer few opportunities to influence the pace of work and participation contributed to the onset of BS, however, communication and contact with colleagues appeared as regulatory factors for prevention. An additional study with Austrian teachers early in their careers indicated that the profession's uncertainty and insecurity is a triggering source of burnout. ${ }^{35}$

BS is a serious disease in which many professionals even consider the possibility of giving up the profession, especially on the part of those whose profession is characterized by caring for people. This is what Soler et al. ${ }^{36}$ found with professionals in Argentina, Colombia and Spain. The same researchers found that $4 \%$ of the workers surveyed (464) had realized that the burnout syndrome affected family relationships.

\section{The management of psychosocial factors at work as a solution to reduce the number of illness}

As a way to prevent BS, there needs to be a change in the work environment, like what happens in several companies in the world, making it a more relaxeble and healthy place. In this organizational climate, it is also important for workers to be heard by managers in addition to promoting psychological listening mechanisms in the workplace. ${ }^{37,38}$

An important element is a new company vision in which gives greater autonomy to its employees together with the improvement of the management of psychosocial factors that triggers stress in the work environment $t^{39}$ how to avoid high turnover and promotion security and stability mechanisms.

\section{Conclusions}

Burnout syndrome still been an unknown disease for health professionals ${ }^{40}$ and when diagnosed it is treated as a secondary disease alongside depression and anxiety, needing greater dissemination so offers an effective prevention and treatment.

It is a global disease (pandamic) that negatively affects the physical and psychological health of workers and the effectiveness of organizations, so it must be treated. The present study pointed to several epidemiological studies in both western and eastern countries, and on all continents.

Unfortunately it is a phenomenon that grows reaching practically all countries in the world. According to data mentioned above, both poor and in developing countries, as well as countries with high economic development and high Human Develovement Index ( HDI). Regarding to its difficulty in the scientific environment, national and international, establishig a single explanatory model, perhaps due to its complexity and multidimension. However, in the field of Psychology, the model adopted by Behavior Analysis, which removes a mentalist explanation, it is the closest scientifically, but studies in this field of knowledge are still scarce. In the international literature, specialized journals in Behavior Analysis do not have theoretical or experimental studies on the subject. However, in the internal Brazilian field. Theoreticaly it has already found some space..$^{41-46}$

\section{Acknowledgments}

None. 


\section{Conflicts of interest}

Author declare that there is no conflict of interst.

\section{References}

1. Maslach C. Jackson, SE. The measurement of experienced burnout Journal of Occupational Behavior. 1981;2(1):99-113.

2. Maslach C, Leiter MP. The truth about burnout: How organization cause, personal stress and what to do about it. San Francisco: Jossey-Bass. 1997.

3. Maslach C, Schaufeli WB, Leiter MP. Job burnout. Annual Review Psychology. 2001;52(1):397-422.

4. Franco G. Prevention is far better than cure - Revisiting the past to strengthen the present: the lesson of Bernardino Ramazzini (1633-1714) in public health (Contents - Preface - Overview). Italy: Youcanprint. 2020.

5. Silva JC, Paschoarelli LC. A evolução histórica da ergonomia no mundo e seus pioneiros. São Paulo: Editora UNESP/Cultura Acadêmica. 2010.

6. Engles F. A situação da Classe trabalhadora na Inglaterra - segundo as observações do autor e fontes autênticas. São Paulo: Boitempo. 2008.

7. Freudenebberger HS. Staff burn-out. Journal of Social Issues. 1974;30(1):159-165.

8. Martinéz IMM, Pinto AM. Burnout em estudiantes universitários de Espana y Portugal y su relación com variables acadêmicas. Aletheia, Canos. 2005;21:21-30.

9. Silva JLL, Souza AC, Soares RS, et al. Prevalência da Síndrome de Burnout entre trabalhadores hidroviários. Revista de Enfermagem da UERJ. 2018;26:e26131:1-6.

10. Bakker AB, Schaufelli WB. Positive organizational behavior: Engaged employees in flourishing organizations. Journal of Organizational Behavior. 2008;29:147-154.

11. Artal FJC, Vazquez-Carrera C. Burnout syndrome in na international setting. In Burnout for Experts (Book). 2013;14-31.

12. Hyeda A, Hamdar Z. Avaliação da produtividade na síndrome de burnout Revista Brasileira de Medicina do Trabalho. 2011; 9(2):78-84

13. Lee RT, Ashforth BE. A further examination of managerial burnout: toward na integrated model. Journal of Organizational Behavior $1993 ; 14(3) ; 3-20$

14. Villaverde D, Unda S, Escotto E, et al. Personality traits that predict the burnout syndrome on mexican teachers. Propósitos y Representaciones. 2019;7(3):41-71.

15. Ramirez DRZ, Moreno MP, Beltran CA, et al. Burnout y work engagement em docentes universitários de Zacatecas. Ciencia \& Trabajo. 2014;16(50):116-120.

16. Saborio Morales L, Hidalgo Murillo LF. Síndrome de Burnout. Medicina Legal de Costa Rica. 2015;32(1):119-124.

17. Bianchini Mataroso M. El síndrome del burnout en personal profesiona de la salud. Medicina Legal de Costa Rica. 1997;13-14(2-1-2):189-192.

18. Diaz Araya S. Comportamiento del síndrome de desgaste profesional en médicos que laboraron en Coopesalud R.L., de agosto a octubre de 2004 Acta Méd Costarric. 2007;49(2):107-110.

19. Mackenzie M, Walker T, Chim C. Prevalence of burnout in bahamian health care Personnel. Journal of Occupational and Environmental Medicine. 2018;60(8):434-435.

20. Grau A, Flichtentrei D, Suner R, et al. Influencia de factores personales, profesionales y transnacionales en el síndrome de burnout en personal sanitario hispanoamericano y español. Revista Espanhola de Salud Publica. 2009;83(2):215-230.
21. Galván MF, Vassallo JC, Rodríguez SP, et al. Síndrome de desgaste profesional (burnout) en médicos de unidades de cuidados intensivos pediátricos en la Argentina. Revista de la Sociedad Boliviana de Pediatría. 2014;53(1):29-36.

22. Torre M, Santos Popper MC, Bergesio A. Burnout prevalence in intensive care nurses in Argentina. Enfermeria Intensiva (English Ed.). 2019;30(3):108-115.

23. Marucco AM, Flamenco E, Ragazoli PN. Estudio para evaluar el síndrome de quemarse por el trabajo (burnout) y la calidad de vida laboral en docentes de educación primaria básica (ex EGB 1 y 2) del programa integral para la igualdad educativa del conurbano bonaerense sur. Revista Eletrônica de Inter-Ação Psy. 2004;1(1):19-33.

24. Jiménez AE, Figueroa MJ, Gutiérrez J, et al. Burnout, apoyo socia y satisfacciónlaboral en docentes. Revista Semestral da Associação Brasileira de Psicologia Escolar e Educacional. 2012;16(1):125-134.

25. Faúndez VEO, Gil-Montes PR. Prevalencia del síndrome de quemarse por el trabajo (burnout) em trabajadores de servicios em Chile. Información Psicológica. 2007;91:43-52.

26. Gil-Monte PR, Faúndez. Psychometric properties of the spanish burnout inventory in chilean professionals working to physical disable peaple. The Spanish Journal of Psychology. 2011;14(1);441-451.

27. Bríones Mella D. Presencía de síndrome de burnout em poblaciones policiales vulnerables de carabineros de Chile. Ciência \& Trabajo. 2007;9(24):43-50.

28. World Health Organizational (WHO). Gerenciando as saídas da força de trabalho. 99-119.

29. Hirsch A. Season of hope: economic reform under Mandela and Mbeki. 2005

30. Godfrey S, Thêron J, Visser M. The state of collective bargaining in South Africa: an empirical and conceptual study of collective bargaining. Cape Town: University of Cape Town (Working Paper, n. 07/130). 2007.

31. Olley BO. A comparative study of burnout syndrome among health professionals in a Nigerian teaching hospital. African Journal of Medicine and Medical Sciences. 2003;32:297-302.

32. Fiadzo E, Golembiewski RT, Luo H, et al. Burnout in ghanaian hospitals: phase model fi ndings in sub-saharan Africa. Journal of Health and Human Services Administration. 1997;19:442-466.

33. Ndetei DM, Pizzo M, Maru H, et al. Burnout in staff working at the Mathari psychiatric hospital. African Journal of Psychiatry. 2008;11:199-203.

34. Thomas LS, Valli A. Levels of occupational stress in doctors working in a South African public-sector hospital. South African medical journal. 96;1162-1168.

35. Talbot K, Mercer S. Exploring university ESL/EFL teachers' emotional well-being and emotional regulation in the United States, Japan and Austria. Chin J Appl. Linguist. 2018;41:410-432.

36. Suñer-Soler R, Grau-Martin A, Flichtentrei D, et al. The consequences of burnout syndrome among healthcare professionals in Spain and Spanish speaking Latin American countries. Burnout Research. 2004;1(2):82-90.

37. Amaral GA. Escuta clínica do trabalho e (re)significação do sofrimento de professoras readaptadas. 2018.

38. Duarte FS. Dispositivos para a escuta clínica do sofrimento no trabalho: entre a clínica da cooperação e das patologias. 2014;142.

39. Moreira Amanda Sorce, Lucca Sergio Roberto de. Fatores psicossociais e Síndrome de Burnout entre os profissionais dos serviços de saúde mental. Revista Latino-Americana de Enfermagem. 2020;28:e3336.

40. Lima FD, Buunk AP, Araújo MBJ, et al. Síndrome de Burnout em residentes da Universidade Federal de Uberlândia-2004. Revista Brasileira de Educação Médica. 2007;31(2);137-146. 
41. Schmitz GA. Síndrome de Burnout: uma proposta de análise sob o enfoque analítico-Comportamental. 2015.

42. Schmitz GA, Soares MRZ. Saúde Mental na Universidade - a compreensão da Síndrome de Burnout em universitários a partir da Análise do Comportamento. Revista Idealização. 2019;21(1):e-ISSN:1982-3010.

43. Hutcheson S, Dean N, Campbell H, et al. The impacton COVID-19 control measures on stress in the Bahamas. Project Social Issues in The Bahamas. 2020;1-12.
44. Organização Panamericana de Saíde/Brasil. CID: burnout é um fenômeno ocupacional. Brasília, OPAS. 2020.

45. Lizano EL, Sapozhnikoc BL. Exploring the meaning of job burnout beyond the Western context: A study of Salvadoran social workers. International Social Work. 2018;21(6);857-8661.

46. Onylezugbo E, Nawfor C. Construct validation of nurse's self-concept questionnaire in Nigeria. European Journal of Social Sciences. 2010;15:467-474 